\title{
Don't Misunderestimate the Donald (Like we did)
}

\author{
Guthey, Eric
}

Document Version

Accepted author manuscript

Published in:

Television \& New Media

DOI:

10.1177/1527476416652697

Publication date:

2016

License

Unspecified

Citation for published version (APA):

Guthey, E. (2016). Don't Misunderestimate the Donald (Like we did). Television \& New Media, 17(7), 667-670. https://doi.org/10.1177/1527476416652697

Link to publication in CBS Research Portal

\section{General rights}

Copyright and moral rights for the publications made accessible in the public portal are retained by the authors and/or other copyright owners and it is a condition of accessing publications that users recognise and abide by the legal requirements associated with these rights.

Take down policy

If you believe that this document breaches copyright please contact us (research.lib@cbs.dk) providing details, and we will remove access to the work immediately and investigate your claim. 


\section{Don't Misunderestimate the Donald (Like we did) Eric Guthey \\ Journal article (Post print version)}

CITE: Don't Misunderestimate the Donald (Like we did). / Guthey, Eric. In: Television \& New Media, Vol. 17, No. 7, 2016, p. 667-670.

DOI: 10.1177/1527476416652697

Uploaded to Research@CBS: June २०17 


\section{Don't Misunderestimate The Donald (Like We Did)}

The half-life of academic analysis dwindles every day in inverse proportion to the mounting rush of trivial ephemerata delivered on the nanosecond via Twitter, Instagram, Yik Yak, or some such new app. No surprise, then, that the spectacle of Donald Trump's Twitter-boosted campaign for president calls into question some of the central arguments my co-authors and I made seven years ago in our book Demystifying Business Celebrity (Guthey, Clark, \& Jackson, 2009).

We said it was a mistake to conceive of business celebrities as "exceptional persons," as many scholars had previously done, because celebrities are not really persons at all, but rather "elaborate constructions that would not exist as celebrities save for the intervention and interaction of a variety of different actors and intermediaries" (Guthey et al., 2009: 145). On this fashionably postmodern basis we avoided discussions about what it's like to meet "the Donald" or about what makes Richard Branson "tick." Instead, we foregrounded the crowded, industrial process of celebrification, which we defined as "the orchestrated co-production, cross-promotion, and circulation of exemplary business personalities via a wide range of media platforms and channels" (Guthey et al., 2009: 145).

This argument now risks appearing quaintly misguided, and not only because we didn't take sufficient account of the burgeoning impact of social media on the phenomenon of celebrity. Although we did not intend to dismiss or to denigrate all business celebrities as shams, neither did we hesitate to take back-handed pot shots at Trump —at one point summing up the widely shared (we said) view that he was a "self-promoting fake who can't stop himself from mugging for the cameras" (Guthey et al., 2009: 150).

Hopefully we can be excused for so casually dismissing Trump as a minor phenomenon of no real import, along with the many other skeptics who have had to adjust, week by week over the 
last year, to the unsettling realization that Trump will most likely become the Republican nominee for president. In retrospect, our more fundamental intellectual mistake was to imply in general that individuals like Trump don't matter, because they are the by-products of industrial and cultural processes beyond anyone's control.

Even though Trump hit his true celebrity stride with a tackily over-produced reality show, many of his supporters clearly feel that he is authentic, and that they have direct access to his very real emotions - specifically to his blind rage, which many of them are happy to share. They appear to value Trump as the ultimate un-groomed, non-manufactured candidate for office, one without handlers and pollsters who calculate everything he says and does. Trump detractors delude themselves every time they think he's gone too far with his next racist, sexist, mean-spirited, violent, or just plain ignorant outburst - all of this only fans the flames of support because it makes him seem more "real".

If we can publish an editorial correction a full seven years after the fact, here it is: THE ACTUAL INDIVIDUAL NAMED DONALD J. TRUMP MATTERS. The interesting question is exactly how Trump matters, and why.

Last fall several prominent psychiatrists and psychologists decided out of conscience to transgress the "Goldwater rule" (established after 1964 presidential candidate Barry Goldwater sued Fact magazine for polling psychiatrists about his mental health) against commenting publicly on anyone's psychological profile without an actual examination and the patient's consent. Harvard psychologist Howard Gardner, clinical psychologists George Simon and Ben Michaelis, psychotherapist Charlotte Prozan, and several others all agreed that Trump quite obviously displays the classic symptoms of narcissistic personality disorder, a condition closely related to histrionic, borderline, and antisocial personality disorder. "Narcissism is an extreme defense against one's own feelings of worthlessness," explained Michaelis. "To degrade people is really part of a cluster-B 
personality disorder: it's antisocial and shows a lack of remorse for other people. The way to make it O.K. to attack someone verbally, psychologically, or physically is to lower them. That's what he's doing" (Alford, 2015).

Trump's pathology is so astonishingly in-your-face and so unseemly; his addiction to media attention and "winning" so craven; his failures, bankruptcies and improprieties so well documented. It just seems impossible to many observers that anyone could view him as a plausible candidate for president. Here our arguments about business celebrity can provide some insight.

We placed our account of business celebrity in the context of the rise of big business in the $19^{\text {th }}$ century, a social transformation that challenged previous conceptions of the individual's place in society by tilting the supposedly level playing field of the marketplace into a jagged landscape of unequal power relations, with a few wealthy individuals occupying the high ground and everyone else toiling down below. Regardless of the class, family, and boardroom connections that enabled their rise, and regardless of the sweat and suffering of the countless workers whose surplus labor sustained them, certain business moguls became symbols of the ideal that individuals could still "make it," that singular (male) human agency could still win out against vast business bureaucracies and economic forces beyond any individual's control (Guthey et al., 2009).

Fast forward a century and a half; exacerbate the disparity between the masses and the one percent; dismantle the progressive safety net woven to catch the victims of such cruel inequities; finish the job the Robber Barons started by smashing unions; ramp up gender, ethnic, religious, and racial diversity to provide false targets for the fears of a destabilized white male workforce; reinforce a gun culture that renders extreme violence commonplace; usher in a Republican party eager to enable and to exploit racist, sexist, birtherist, and fundamentalist phobias for political gain; and provide a multitude of social media outlets for the pent-up fury and helplessness that results 
from all this. As Noam Chomsky recently described this volatile mix in shorthand, "Trump is winning because white America is dying" (Ferner, 2016).

Trump's candidacy is succeeding because it feeds on a set of deteriorating cultural and economic conditions that his candidacy will also in turn serve to make worse. This is the context in which Trump and his inner demons matter. He is not a figure of agency or hope but a flashpoint for belligerence, anger, ignorance, and hate. What we missed in our book was the reality that the tinhorn reality star Donald Trump, with his orange hair and his opera-buffa backstory, had it within him to transcend the bounds of business celebrity, enabled by the industrial process of celebrification itself, to become a powerful and dangerous modern demagogue.

Alford, H. 2015, November 11. Is Donald Trump Actually a Narcissist? Therapists Weigh In! Vanity Fair. http://www.vanityfair.com/news/2015/11/donald-trump-narcissism-therapists. Ferner, M. 2016, February 26. Donald Trump Is Winning Because White America Is Dying. The Huffington Post. http://www.huffingtonpost.com/entry/donald-trump-noam-chomskywhite-mortality_us_56cf8618e4b0bf0dab31838f.

Guthey, E., Clark, T., \& Jackson, B. 2009. Demystifying business celebrity. London, New York: Routledge. 